Halimatus Saidah, SST., M.HKes, Wilda Al aluf, Hubungan Antara Tingkat Kecemasan Emosional Ibu Post Partum Dengan Kejadian Post Partum Blues Di Kelurahan Sukorame Wilayah Kerja Puskesmas Sukorame Kediri Tahun 2018

\title{
HUBUNGAN ANTARA TINGKAT KECEMASAN EMOSIONAL IBU POST PARTUM DENGAN KEJADIAN POST PARTUM BLUES DI KELURAHAN SUKORAME WILAYAH KERJA PUSKESMAS SUKORAME KEDIRI TAHUN 2018
}

\author{
Halimatus Saidah, SST., M.HKes \\ Wilda Al aluf, S.Tr.Keb \\ Program Studi Kebidanan (DIV) \\ Fakultas IImu Kesehatan Universitas Kadiri
}

\section{ABSTRAK}

Hubungan tingkat kecemasan emosional ibu Post Partum dengan kejadian Post Partum Blues sangat penting diketahui karena pada fase ini terjadi perubahan secara fisiologis maupun secara psikologis yang dapat mempengaruhi kelabilan emosional ibu setelah melahirkan. Tujuan dari penelitian ini untuk mengetahui hubungan tingkat kecemasan emosional ibu Post Partum dengan kejadian Post Partum Blues yang ada dikelurahan sukorame wilayah kerja puskesmas sukorame.

Desain yang digunakan pada penelitian ini menggunakan analitik korelasional dengan pendekatan Cross Sectional. Sampel penelitian menggunakan teknik Purposive Sampling, diperoleh jumlah sampel 24 orang responden dengan kriteria responden yaitu ibu Post Partum hari ke 7- minggu ke 2, nifas normal. Pengumpulan data menggunakan lembar ceklist skala Hamilton Anxiety Rating Scale dan kuesioner Edinburgh Post Natal Depression Scale. Analisa data menggunkan uji Sperman Rank.

Tingkat kecemasan emosional ibu post partum sebagian kecil $(25,0 \%)$ yaitu 6 responden. dan kejadian Post Partum Blues sebagian besar (62,5\%) yaitu 15 responden. Hasil analisa data dengan menggunakan uji Spearmen Rank didapatkan hasil $p$-value $0,000<$ taraf signifikan $(\alpha=0,05)$ dengan demikian ada hubungan antara tingkat kecemasan emosional ibu post partum dengan kejadian Post Partum Blues di Kelurahan Sukorame wilayah Kerja Puskesmas Sukorame. Dan nilai koefisien ( $r$ ) sebesar 0,859 kekuatan korelasi dalam kategori sangat kuat dengan arah positif.

Dari hasil penelitian ini dapat disimpulkan adanya hubungan antara tingkat kecemasan emosional ibu post partum dengan kejadian Post Partum Blues di kelurahan Sukorame wilayah kerja Puskesmas Sukorame.

Kata Kunci: Tingkat Kecemasan, Post Partum, dan Kejadian Post Partum Blues

\section{ABSTRACT}

The relationship between the level of emotional anxiety of the mother of post partum with Post Partum Blues occurrence is very important because in this phase there is a change physiologically and psychologically wich can affect the emotional stability of mother after giving birth.

The purpose of this study to determine the relationship of emotional anxiety level of post partum mother with Post Partum Blues incident that exist in sukorame's Village its work area of puskesmas Sukorame.

Design used correlational analytics with cross sectional approach. The sample research using purposive sampling technique, obtained the number of samples 24 respondents with the criteria of respondents is post partum mother day 7 to week 2, its good puerperium. Data's collection using hamilton anxiety rating scale and Edinburgh Postnatal Depression Scale. Data's processing is interpreted according to the classification of each measuring instrument.

The result of the research showed that the relationship of emotional anxiety level of post partum mother with Post Partum Blues incidence was the amount of the anxiety level $12,5 \%$, $25 \%$ heavy anxiety, medium anxiety $16,6 \%$ and mild anxiety $20,9 \%$ with Post Partum Blues event. While those without anxiety were $0 \%$ for Post Partum Blues event.

From the result of this study it can be concluded that almost all postpartum mothers with anxiety that there is in the field of Sukorame work area puskesmas Sukorame experience Post Partum Blues. As for recommendation of this research is holding counseling about how to handle Post Partum Blues.

Key Word : Anxiety level, Post Partum, Post Partum Blues Event 


\section{PENDAHULUAN}

Periode post partum atau masa nifas merupakan situasi krisis bagi ibu, pasangan dan keluarga akibat berbagai perubahan yang terjadi baik secara fisik, psikologis, maupun struktur keluarga yang memerlukan proses adaptasi atau penyesuaian. Adaptasi secara fisik dimulai sejak bayi dilahirkan sampai kembalinya kondisi tubuh ibu pada kondisi seperti sebelum hamil, yaitu pada kurun waktu 6 sampai 8 minggu setelah persalinan. Sedangkan psoses adaptasi psikologi pada seorang ibu sudah dimulai sejak hamil (Murray, dkk.,2007).

Dalam periode post partum, $85 \%$ ibu postpartum dapat mengalami gangguan psikologi. Ada yang menunjukkan gejala yang ringan dan tidak berlangsung lama, namun adapula sampai 10 hingga $15 \%$ mengalami gejala yang lebih signifikan seperti depresi atau kecemasan. Dengan uraian diatas bahwa seorang wanita yang memiliki riwayat neurotis, cemas, dan depresi selama kehamilan akan meningkatkan resiko terjadinya Post Partum Blues . ( Miller, dkk.,2015).

Berdasarkan data dari World Health Orgaisation (WHO) pada tahun 2010 diperkirakan bahwa Post Partum Blues ringan kejadinya 10 per 1000 kelahiran hidup dan Post Partum Blues sedang atau berat berkisar 30 sampai 200 per 1000 kelahiran hidup (Salma, 2012). Angka kejadian Post Partum Blues di Asia cukup tinggi dan sangat bervariasi antara 26$85 \%$, sedangkan di Indonesia angka kejadian Post Partum Blues antara 50-70\% dari wanita pasca persalinan (Rahmi, 2012). Berdasarkan hasil dari Centers for Disease Control and Prevention (CDC) prevalensi depsresi postpartum berkisar antara $11,7 \%$ sampai $20,4 \%$ pada tahun 2004-2005 (Nasution, 2012). Di Indonesia angka kejadian postpartum blues antara 50-70\%. (Elvira, 2011).

Berdasarkan hasil studi pendahuluan yang dilakukan di kelurahan sukorame terdapat 10 ibu post partum, dengan 5 $(50 \%)$ ibu post partum yang mengalami Post Partum Blues dan $5(50 \%)$ ibu post partum yang tidak mengalami Post Partum Blues . Dari data terlihat masih adanya kejadian Post Partum Blues sekitar $50 \%$ dari ibu yang mengalami post partum, hampir keseluruhan ibu post partum tidak mengetahui tanda dan gejala dari Post Partum Blues sehingga banyak yang tidak memperdulikan kejadian seperti Post Partum Blues ini.

Penyebab postpartum blues dapat disebabkan oleh faktor hormonal, faktor demografi yaitu umur dan paritas, pengalaman ibu dalam proses kehamilan dan persalinan, latar belakang psikososial ibu yang takut kehilangan bayinya atau kecewa dengan bayinya (Ambarwati, 2008).

Menurut Diah Ayu Fatmawati dalam penelitiannya yang berjudul Faktor Risiko Yang Berpengaruh Terhadap Kejadian Postpartum Blues bahwa Faktor risiko yang paling berpengaruh terhadap kejadian postpartum blues pada ibu postpartum adalah factor usia yaitu usia $\leq$ 20 tahun dibandingkan factor pendidkan, paritas, dukungan social suami, di Puskesmas wilayah kerja Kota Yogyakarta (Diah Ayu, 2015)

Dampak dari Baby Blues( Post Partum Blues) berpengaruh terhadap perkembangan anak karena stress , pemberian ASI (Air Susu lbu) sehingga kebutuhan nutrisi tidak terpenuhi dan bisa membuat bayi tumbuh menjadi anak yang mudah menangis, cenderung rewel, pencemas, pemurung dan mudah sakit, (leira, anidya, 2008). Sedangkan dampak mikro Postpartum Blues adalah lbu merasakan kesedihan karena menjadi tidak bebeas lagi, interaksi sosial, kurang kemandirian. (Manuaba, 2007).

Postpartum blues dapat diatasi dengan banyak istirahat dan dukungan lingkungan yaitu suami, keluarga, juga teman dekat si ibu dan bidan sebagai sarana penyampaian informasi. Dalam menjalankan peran bidan sebagai pendidik dapat meningkatkan pengetahuan ibu tentang Post Partum Blues dengan memberikan informasi melalui penyuluhan supaya ibu post partum yang mengalami Post Partum Blues tidak jatuh pada depresi atau gangguan jiwa (lisna dkk., 2015). Selain itu suami dan keluarga juga harus selalu memberikan dukungan penuh pada ibu maka ibu akan tenang dan tidak merasa terbebani, sehingga ibu akan merasa nyaman dan relaks. Maka apabila mengalami gejala-gejala postpartum blues segeralah memberitahu suami, bidan atau dokter. Perawatan di rumah sakit akan 
Halimatus Saidah, SST., M.HKes, Wilda Al aluf, Hubungan Antara Tingkat Kecemasan Emosional Ibu Post Partum Dengan Kejadian Post Partum Blues Di Kelurahan Sukorame Wilayah Kerja Puskesmas Sukorame Kediri Tahun 2018

diperlukan apabila ibu mengalami depresi berkepanjangan (Wiknjosastro, 2008).

\section{METODE PENELITIAN}

Rancangan penelitian ini adalah rancangan penelitian inferensial dengan pendekatan Cross Sectional. Sampel yang digunakan dalam penelitian ini yaitu sebagian dari ibu post partum di Kelurahan Sukorame Kota Kediri Tahun 2018 sebanyak 24 orang yang diambil dengan menggunakan metode Purposive Sampling. Variabel independent pada penelitian ini adalah tingkat kecemasan emosional ibu post partum yang diukur dengan menggunakan Lembar ceklist menurut HARS (Hamilton Anxiety Rating Scale) dan Variabel dependent adalah kejadian Post Partum Blues diukur dengan menggunkan Kuesioner dengan skala EPDS (Edinburgh
Postnatal Depression Scale. Analisis data yang digunakan dalam penelitian ini adalah dengan menggunakan analisis univariat dan analisa bivariat dengan menggunakan uji Spearmen Rank dengan derajat kepercayaan $95 \% \quad(\alpha=0,05)$ sehingga dibuat kesimpulan jika Jika $p$ value $\leq 0,05$, maka ada hubungan antara tingkat kecemasan emosional pada ibu post partum dengan kejadian Post Partum Blues dan Jika $p_{\text {_value }} \geq 0,05$ signifikan 0,05 maka tidak ada hubungan antara tingkat kecemasan emosional pada ibu post partum dengan kejadian Post Partum Blues selanjutnya dicari kekuatan hubungan antara tingkat kecemasan emosional ibu post partum terhadap kejadian Post Partum Blues yang dapat diketahui dari besar kecilnya angka dalam index korelasi (Coefisien Correlation).

\section{HASIL PENELITIAN}

Tabel 1 Karakteristik Responden Berdasarkan Umur

\begin{tabular}{lll}
\hline Usia & Frekuensi $(\mathrm{f})$ & Prosentase $(\%)$ \\
\hline$<20$ tahun & 11 & 45,9 \\
$20-35$ tahun & 9 & 37,5 \\
$>35$ tahun & 4 & 16,6 \\
\hline Jumlah & 24 & 100
\end{tabular}

Berdasarkan tabel 1 dapat diketahui bahwa hampir sebagian responden (45,9\%) yang berusia $<20$ tahun yaitu sebanyak 11 orang.

Tabel 2 Karakteristik Responden Berdasarkan Pendidikan

\begin{tabular}{lll}
\hline Pendidikan & Frekuensi (f) & Prosentase $(\%)$ \\
\hline SD/SMP & 13 & 54,2 \\
SMA & 7 & 29,2 \\
Sarjana & 4 & 16,6 \\
\hline Jumlah & 24 & 100 \\
\hline
\end{tabular}

Berdasarkan tabel 2 dapat diketahui bahwa sebagian besar responden (54,2\%) berpendidikan SD/SMP yaitu sebanyak 13 orang.

Tabel 3 Karakteristik Responden Berdasarkan Pekerjaan

\begin{tabular}{lll}
\hline Pekerjaan & Frekuensi (f) & Prosentase $(\%)$ \\
\hline Bekerja & 15 & 62,5 \\
Tidak bekerja & 9 & 37,5 \\
\hline Jumlah & 24 & 100
\end{tabular}

Berdasarkan tabel 3 dapat diketahui bahwa sebagian besar responden $(62,5 \%)$ yang bekerja yaitu sebanyak 15 orang.

Tabel 4 Karakteristik Responden Berdasarkan Paritas

\begin{tabular}{lll}
\hline Pendidikan & Frekuensi (f) & Prosentase (\%) \\
\hline Primipara & 14 & 58,3 \\
Multipara & 7 & 29,2 \\
Grandemulti & 3 & 12,5 \\
\hline Jumlah & 24 & 100 \\
\hline
\end{tabular}


Halimatus Saidah, SST., M.HKes, Wilda Al aluf, Hubungan Antara Tingkat Kecemasan Emosional Ibu Post Partum Dengan Kejadian Post Partum Blues Di Kelurahan Sukorame Wilayah Kerja Puskesmas Sukorame Kediri Tahun 2018

Berdasarkan Tabel 4 dapat diketahui bahwa sebagian besar paritas responden $(58,3 \%)$ primipara yaitu sebanyak 14 orang.

Tabel 5 Tingkat Kecemasan Emosional Ibu Post Partum

\begin{tabular}{lll}
\hline Tingkat Kecemasan & Frekuensi (f) & Prosentase (\%) \\
\hline Tidak ada Kecemasan & 4 & 16,6 \\
Kecemasan ringan & 5 & 20,9 \\
Kecemasan sedang & 6 & 25,0 \\
Kecemasan berat & 6 & 25,0 \\
Kecemasan berat sekali & 3 & 12,5 \\
\hline Jumlah & 24 & 100 \\
\hline
\end{tabular}

Berdasarkan Tabel 5 menunjukkan bahwa sebagian kecil responden $(25,0 \%)$ dengan kecemasan sedang yaitu 6 orang dan kecemasan berat yaitu 6 orang.

Tabel 6 Kejadian Post Partum Blues

\begin{tabular}{lll}
\hline Kejadian Post Partum Blues & Frekuensi (f) & Prosentase (\%) \\
\hline Normal & 9 & 37,5 \\
Post Partum Blues & 15 & 62,5 \\
Depresi & 0 & 0 \\
\hline Jumlah & 24 & 100
\end{tabular}

Berdasarkan Tabel 6 dapat diketahui bahwa sebagian besar responden (62,5\%) yang mengalami Post Partum Blues yaitu sebanyak 15 orang.

Tabel 7 Hubungan Antara Frekuensi Tingkat Kecemasan Ibu

\begin{tabular}{|c|c|c|c|c|c|c|c|c|}
\hline \multirow{2}{*}{$\begin{array}{c}\text { Tingkat } \\
\text { kecemasan }\end{array}$} & \multicolumn{8}{|c|}{ Kejadian Post Partum Blues } \\
\hline & Normal & $\%$ & $\begin{array}{l}\text { PP } \\
\text { Blues }\end{array}$ & $\%$ & Depresi & $\%$ & Total & $\%$ \\
\hline $\begin{array}{ll}\text { Tidak } & \text { ada } \\
\text { kecemasan } & \end{array}$ & 4 & 16,6 & 0 & 0 & 0 & 0 & 4 & 16,6 \\
\hline $\begin{array}{l}\text { Kecemasan } \\
\text { Ringan }\end{array}$ & 3 & 4,16 & 2 & 8,3 & 0 & 0 & 5 & 20,9 \\
\hline $\begin{array}{l}\text { Kecemasan } \\
\text { Sedang }\end{array}$ & 2 & 8,3 & 4 & 16,6 & 0 & 0 & 6 & 25,0 \\
\hline Kecemasan Berat & 0 & 0 & 6 & 25,0 & 0 & 0 & 6 & 25,0 \\
\hline $\begin{array}{l}\text { Kecemasan Berat } \\
\text { Sekali }\end{array}$ & 0 & 0 & 3 & 12,5 & 0 & 0 & 3 & 12,5 \\
\hline Jumlah & 9 & 37,5 & 15 & 62,5 & 0 & 0 & 24 & 100 \\
\hline$\rho \_$Value $=0,000$ & & $\alpha=$ & & & $r=c$ & & & \\
\hline
\end{tabular}

Hasil penghitungan data penelitian dengan menggunakan uji Spearmen Rank dengan penghitungan software pada tingkat kemaksimalan $(\alpha=0,05)$ didapatkan nilai $p$-value 0,000 dan nilai tersebut $<$ taraf signifikan $(\alpha=0,05)$ yang berarti ada hubungan antara tingkat kecemasan emosional ibu post partum dengan kejadian Post Partum Blues, sementara itu nilai $\mathrm{Cl}(\mathrm{r})$ sebesar 0,859 menunjukkan hubungan antara frekuensi tingkat kecemasan emosional dan kejadian Post Partum Blues memiliki korelasi dalam hubungan sangat kuat dengan arah positif, yang artinya semakin berat tingkat kecemasan maka angka kejadian post partum blus akan semakin tinggi.

\section{PEMBAHASAN}

Berdasarkan hasil penelitian yang tertera di tabel 5 menunjukan bahwa dari 24 responden dengan kecemasan sedang yaitu $6(25,0 \%)$ orang dan kecemasan berat yaitu 6 orang $(25,0 \%)$. 
Hasil penelitian ini sesuai dengan penelitian yang dilakukan oleh Hendri (2009) dengan sampel 38 orang, menunjukkan bahwa sebagian besar responden mengalami tingkat kecemasan ringan $(44,7 \%)$, kecemasan sedang $(28,9 \%)$ dan kecemasan berat $(26,3 \%)$.

Dalam Handerson dan Jones (2006) juga menyatakan bahwa perubahan selama kehamilan khususnya peningkatan hormon dapat menimbulkan tingkat kecemasan yang semakin berat serta rasa khawatir menerima peran baru menjadi orang tua. Krisis situasi ini dapat dapat menimbulkan terjadinya kecemasan pada masa nifas. Sri Y., (2014).

Kecemasan yang berlebihan dapat menyebabkan ibu merasa takut tanpa alasan yang jelas, ibu mengalami kesulitan untuk istirahat dan tidur serta sering mengalami gejala gangguan fisik yaitu sakit kepala dan leher. Berat ringannya respon cemas yang timbul dapat tergantung pada kematangan pribadi, pemahaman dalam menghadapi tantangan, harga diri, mekanisme koping yang digunaka dan mekanisme pertahanan diri yang digunakan untuk mengatasi kecemasannya

Berdasarkan hasil penelitian yang tertera pada table 6 dari 24 responden menunjukkan bahwa sebagian besar responden yang mengalami Post Partum Blues yaitu sebanyak 15 orang $(62,5 \%)$.

Hasil penelitian menunjukkan bahwa angka kejadian ibu post partum yang mengalami Post Partum Blues cukup tinggi. Tingginya prosentase ibu post partum yang mengalami Post Partum Blues tentunya didukung oleh berbagai penyebab.

Hasil penelitian pada tabel 7 menunjukkan bahwa dari 24 responden sebagian kecil angka kejadian Post Partum Blues $(25,0 \%)$ yang mengalami tingkat kecemasan berat yaitu 6 orang.

Berdasarkan hasil uji statistik Spearmen $R$ antara tingkat kecemasan emosional ibu post partum dengan kejadian Post Partum Blues didapatkan $p$-value $=0,000$ lebih kecil dari nilai $\alpha=0,05(0,000<0,05)$ sehingga $\mathrm{H} 0$ ditolak dan $\mathrm{H} 1$ diterima. Sedangkan keeratan hubungan dilihat dari Correlation Coefisien $=0,859$ artinya mempunyai keeratan hubungan antara tingkat kecemasan emosional ibu post partum dengan kejadian Post Partum Blues. Adapun arah korelasi hubungan adalah postif, artinya semakin tinggi tingkat kecemasan ibu maka akan semakin tinggi ibu post partum mengalami kejadian Post Partum Blues .

Menurut Sadock dalam kirana (2015), cemas merupakan manifestasi langsung dari stress ada hubungannya dengan pola kehidupan, rasa cemas yang tidak bisa ditanggulangi oleh ibu hamil sangat berdampak tidak baik, hal tersebut mengakibatkan terjadinya vasokonstriksi pembuluh darah dan metabolisme tidak seimbang. Selain itu Biben (2009) mencoba menelaah pemicu penderitaan kaum ibu, bahwa dia menduga hal itu sebagai akumulasi kecemasan yang terkumpul selama kehamilan sehingga akan berdampak pada persalinandan post partum, juga pada saat seseorang mengalami kecemasan dari segi hormonal diantaranya terjadi perubahan kadar estrogen, progesteron, prolaktin dan estriol yang terlalu rendah atau terlalu tinggi yang berfluktuasi. Bila ibu post partum mengalami penurunan kadar estrogen secara bermakna dan estrogen memiliki efek supresi aktiviti enzyme monoaminase oksidase yaitu suatu enzyme ke otak yang bekerja menginaktifasi baik noradenalin maupun serotonin yang berperan dalam suasana satu terjadinya cemas sebagai salah satu terjadinya Post Partum Blues .

Hasil penelitian menunjukkan bahwa tingkat kecemasan memperoleh jumlah yang cukup tinggi menyebabkan kejaidan postpartum blues. Banyaknya ibu post partum yang mengalami kecemasan menurut hasil penelitian terlihat bahwa terdapat gejala seperti ibu merasa takut tanpa alasan yang jelas, ibu mengalami kesulitan untuk istirahat dan tidur serta sering mengalami gejala gangguan fisik yaitu sakit kepala dan leher. Ibu merasa cemas karena ketidak mampuannya untuk merawat bayinya setelah beberapa hari pasca bersalin dan ketakutan menjadi tidak menarik lagi. Karena adanya kecemasan yang dialami oleh ibu post partum sehingga mengakibatkan terjadinya Post Partum Blues .

\section{SIMPULAN}

Berdasarkan hasil penelitian yang telah dilakukan, maka dapat diambil kesimpulan sebagai berikut :

1. Tingkat kecemasan ibu post partum di kelurahan Sukorame Wilayah Kerja Puskesmas Sukorame tahun 2018, sebagian kecil dari responden 
Halimatus Saidah, SST., M.HKes, Wilda Al aluf, Hubungan Antara Tingkat Kecemasan Emosional Ibu Post Partum Dengan Kejadian Post Partum Blues Di Kelurahan Sukorame Wilayah Kerja Puskesmas Sukorame Kediri Tahun 2018

mengalami tingkat kecemasan sedang dan berat.

2. Kejadian Post Partum Blues di Kelurahan Sukorame Puskesmas Sukorame tahun 2018, sebagian besar dari responden mengalami Post Partum Blues

3. Ada hubungan antara tingkat Kecemasan Emosional lbu Post Partum dengan Kejadian Post Partum Blues di Kelurahan Sukorame Wilayah Kerja Puskesmas Sukorame tahun 2018 dengan kekuatan hubungan sangat kuat dan arah korelasi positif.

\section{SARAN}

1. Bagi Pelayanan Kesehatan

Perawat atau bidan bisa memberikan motivasi kesiapan ibu terhadap peran barunya dan pentingnya dukungan keluarga untuk mengurangi kecemasan pada ibu post partum, dan pentingnya penyuluhan tentang Post Partum Blues

2. Bagi Tempat Penelitian

Hasil penelitian ini dapat dijadikan sebagai data dijadikan sebagai data dan masukan untuk membuat pedoman perencanaan dalam mengantisipasi masalah psikologis pada ibu post partum dengan memodifikasi alat ukur kecemasan dengan Endiburg Postnatal Depression Scale (EPDS) dan perlu membentuk tim konseling untuk mebantu dalam penanganan pasien Post Partum Blues .

\section{DAFTAR PUSTAKA}

Ambarwati dan Wulandari,D. 2008. Asuhan Kebidanan Nifas. Yogyakarta: Mitra Cendikia

Arikunto, S. 2010. Prosedur Penelitian Satu Pendekatan Praktik. Jakarta: PT. Rineka Cipta

Dennis CL,. 2007 Can We Idntify Mothers at Risk For Postpartum Depression in the Immediate Postpartum Period Using The Endiburgh Postnatal Depression Scale? Journal of Affective Disordes.

Diah Ayu F. 2015. Faktor Risiko Yang Berpengaruh Terhadap Kejadian PostPartum Blues. Jurnal
EduHealth Vol 5 No.2. 82-93. Jombang

Elvira. S.D., Wibisono, S. Kusuma dewi, I., 2010. Validation study of the Endiburgh Postnatal Depression Scale. Indonesian Psychiatric Quarterly.

Fatimah, S., 2009. Hubungan Dukungan Suami dengan Kejadian Postpartum Blues pada lbu Primipara di Ruang Bugenvil RSUD Tugerejo Semarang. Artikel Riset Keperawatan.

Friedman, 2005. Keperawatan Keluarga. Jakarta : EGC

Jaenuddin Ujam, 2012. Psikologi Transpersonal. Jakarta : Pustaka Pelajar

Kartikasari, B.D., 2007. Hubungan antara Dukungan Sosial dengan Kecemasan dalam Komunikasi Interpersonal. Skripsi. Yogyakarta : Fakultas Psikologi Universitas Gajah Madah

Machmuda,T., 2011. Pengaruh Persalinan dengan Komplikasi Terhadap Kemungkinan Terjadinya Postpartum Blues di Kota Semarang. Tesis Keperawatan Universitas Indonesia

Manuaba, I.B.G. 2007. Gawat Darurat Obstetri Ginekologi dan Ginekologi Sosial Untuk Profesi Bidan. Jakarta : EGC

Murtiningsih Afin, 2012. Mengenal Baby Blues dan Pencegahannya. Jakarta: Niaga Swadaya

Nirwana, A., 2011. Psikologi Ibu, Bayi, dan Anak. Yogyakarta: Nuha Medika

Notoatmodjo,S., 2010. Metodelogi Penelitian Kesehatan. Jakarta: Rineka Cipta

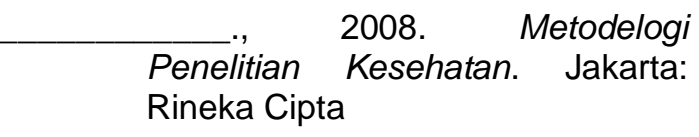


Halimatus Saidah, SST., M.HKes, Wilda Al aluf, Hubungan Antara Tingkat Kecemasan Emosional lbu Post Partum Dengan Kejadian Post Partum Blues Di Kelurahan Sukorame Wilayah Kerja Puskesmas Sukorame Kediri Tahun 2018

Stuart dan Sunden, 2006. Buku Saku Keperawatan Jiwa Alih Bahasa Achir Yani. S. Jakarta: EGC

Suherni, 2009. Perawatan Masa Nifas. Yogyakarta: Fitramaya

Suliswati, 2009. Konsep Dasar Keperawatan Kesehatan Jiwa. Jakarta: EGC

Taufik, 2010. Psikologi untuk Kebidanan. Surakarta: Eastview 